\title{
A Model for Dialogue: Cyprian of Carthage on Ecclesial Discernment
}

Paul J. Fitzgerald S.J.

Fairfield University, pfitzgerald@fairfield.edu

Follow this and additional works at: https://digitalcommons.fairfield.edu/religiousstudies-facultypubs Copyright 1998 Theological Studies

Archived here with permission from the copyright holder.

\section{Peer Reviewed}

\section{Repository Citation}

Fitzgerald, Paul J. S.J., "A Model for Dialogue: Cyprian of Carthage on Ecclesial Discernment" (1998). Religious Studies Faculty Publications. 4.

https://digitalcommons.fairfield.edu/religiousstudies-facultypubs/4

\section{Published Citation}

Fitzgerald, Paul. "A Model for Dialogue: Cyprian of Carthage on Ecclesial Discernment." Theological Studies 59.2 (1998): 236-253.

This item has been accepted for inclusion in DigitalCommons@Fairfield by an authorized administrator of DigitalCommons@Fairfield. It is brought to you by DigitalCommons@Fairfield with permission from the rightsholder(s) and is protected by copyright and/or related rights. You are free to use this item in any way that is permitted by the copyright and related rights legislation that applies to your use. For other uses, you need to obtain permission from the rights-holder(s) directly, unless additional rights are indicated by a Creative Commons license in the record and/or on the work itself. For more information, please contact digitalcommons@fairfield.edu. 


\title{
A MODEL FOR DIALOGUE: CYPRIAN OF CARTHAGE ON ECCLESIAL DISCERNMENT
}

\author{
PAUL J. FITZGERALD, S.J.
}

\begin{abstract}
[Editor's note: To provide theological support for the Common Ground Initiative, the author explores an ancient practice, active participation by the faithful in the process of ecclesial discernment. Cyprian of Carthage consulted broadly and sought communal consensus on such matters as the election of bishops, the readmission of the lapsed, and the deposition of unworthy bishops. Such consultation was considered an essential element in the Church's own fidelity to God.]
\end{abstract}

\begin{abstract}
B EFORE HIS DEATH from cancer in late 1997, Cardinal Joseph Bernardin launched an important venture to improve charitable dialogue within the U.S. Catholic community, a dialogue which he and many judged to have fallen into grave danger due to polarization and acrimony. ${ }^{1}$ The positive and the negative reactions to the Catholic Common Ground Initiative have amply demonstrated the need for chastened forms of intraecclesial communication. The initiative's goal is to foster a renewed dialogue within the Church based upon mutual respect and love as expressions of a common faith in Jesus Christ.

This initiative responds to evolutionary movements within the practice of membership in the U.S. Catholic Church since Vatican II. Over the past 30 years, there has been a notable increase and complexification of broadly based, participative ecclesial dialogue on a whole range of moral issues, church disciplines, and liturgical practices. Groups as diverse in their readings of the signs of the times as Catholics United for the Faith and Call to Action base their involvement on the implicit conviction that church members are called to contribute to the life of the Church in the modern world. ${ }^{2}$ One can only applaud this general
\end{abstract}

PaUl J. FitzGerald, S.J., received his degree "Docteur ès lettres" from the University of Paris IV (La Sorbonne) in 1997. He is now assistant professor of religious studies at Santa Clara University, where he concentrates especially on ecclesiology and historical and practical theology. He has submitted for publication in France a revised version of his dissertation, "L'Eglise comme lieu de formation d'une conscience de la concitoyenneté: Étude sur la rédaction en public de la lettre pastorale Economic Justice for All."

\footnotetext{
${ }^{1}$ Published in a variety of places, the principal documents are presented by Philip J. Murnion in Catholic Common Ground Initiative: Foundational Documents (New York: Crossroads, 1997).

${ }^{2}$ The right and duty of lay Catholics to manifest to bishops all that is helpful for the life of the Church is spelled out in the 1983 Code of Canon Law (c. 212), which itself
} 
trend, for it signals the serious faith commitment of many thousands of U.S. Catholics, both lay and ordained. At the same time, many Catholics, lay and cleric alike, confuse the nature and method of religious discernment, which is proper to the life of the Church, with those of partisan political debate, which is not. The initiative seeks to correct this confusion by refounding ecclesial dialogue on three bases: Christ as the measure of all actions and attitudes, Scripture and tradition as normative foundational sources, and ecclesiastical magisterium, exercised by the bishops and the chair of Peter, as authoritative. Upon this common ground, all Catholics are invited to participate actively in a communal effort to discern the will of God for the Church today.

This invitation holds considerable promise for the U.S. Catholic Church, but it also raises a number of important questions: How ought the laity to participate in ecclesial dialogue? Why should the Church foster broad dialogue? Is such participation merely permitted? Is it recommended as expedient in the current situation? Or is it essential to the nature of the Church and therefore required? Here I explore these questions and attempt to explicitate a theological foundation of the initiative's invitation to ecclesial dialogue.

The phenomenon of active participation of all members in the life of the Church has been addressed in a variety of disciplines, including canon law, recent conciliar and papal teachings, and the work of systematic theologians and ecclesiologists. ${ }^{3}$ To complement these and to undergird the Catholic Common Ground Initiative I wish to look to the distant past with a view to creative retrieval of an ancient church practice. The history of the Church is a vital part of the present reality of the Church. Tradition is the catholic name for salvation history, the ongoing presence and activity of the Holy Spirit in interaction with the

draws upon Lumen gentium no. 37. One could also cite the call in Apostolicam actuositatem no. 2 to active participation of the laity in the life of the Church, and in Gaudium et spes no. 44 on the essential nature of the active participation of all church members in the ecclesial discernment of revealed truth in the context of the modern world.

${ }^{3}$ In February 1980, the Association for the Rights of Catholics was founded. The editors Leonard Swidler and Herbert O'Brien presented some of the fruits of this movement in A Catholic Bill of Rights (Kansas City: Sheed and Ward, 1988). In a number of articles, and especially through his work with the U.S. Catholic Conference of Bishops, J. Bryan Hehir has done much to implement the conciliar ecclesiological teachings; see esp. "Church-State and Church-World: The Ecclesiological Implications," in Catholic Theological Society of America, Proceedings 41 (1986) 54-74. Eugene C. Bianchi and Rosemary Radford Ruether edited a rich collection of articles by leading theologians in A Democratic Catholic Church: The Reconstruction of American Catholicism (New York: Crossroad, 1993). G. Magill's argument for a philosophically and theologically undergirded public discourse also applies, mutatis mutandis, to intraecclesial dialogue; see his "Public Religious Dialogue: The Economic Pastoral and the Hermeneutics of Democracy," TS 54 (1993) 678-97. W. V. D'Antonio gives a good overview from a sociological perspective of the large and growing desire among Catholics for shared decision making in the Church, especially at the parish level, and especially concerning how parish funds are spent; see his "Autonomy and Democracy in an Autocratic Organization: The Case of the Roman Catholic Church," Sociology of Religion 55 (1994) 379-96. 
community of believers. Chesterton happily called tradition "democracy for the dead," indicating that the faith and wisdom of our ancestors, won through faithful openness to God's initiatives for the salvation of humankind, ought to survive into the current search for solutions to contemporary crises. Certainly, Christian communities have lived through periods of rancor in the past, and the Church overcame threats to both orthodoxy and communion through an inclusive dialogue involving all of the faithful members of the community. I examine one such instance, that of third-century Christians in Carthage, despite the significant number of social, cultural, and ecclesial differences that separate us from them. This distance may suggest some timely elements of the tradition at our disposal once again. There is little danger that either the "left" or the "right" of today's Church can irrefutably claim the Carthaginians as issue-allies in the contemporary ecclesial culture wars. Finally, such a comparison may be useful if it allows us to construct analogies and to deepen our courage, both of which seem to be in demand today.

Cardinal Bernardin was not the first bishop who sought to strengthen communion and peace in the Church through the inclusion of all parties in a truly ecclesial dialogue. Thascius Caecilius Cyprianus (c. 200-258) ${ }^{4}$ was elected bishop in 247 by most of the laity and some of the clergy of the Christian community in the second city of the empire. Cyprian embarked upon the rough seas of ecclesial leadership in a stormy time of persecution from without and dissent from within. Throughout his episcopate, Cyprian continued to seek the advice and consent of the laity for his most important actions. ${ }^{5}$ He left an extensive corpus of letters and treatises which provide us a privileged view

\footnotetext{
${ }^{4}$ Our earliest sources for details of Cyprian's life and thought are his own letters and treatises. The standard collection and numbering has been that of G. Hartel's Opera Omnia (Corpus Scriptorum Ecclesiasticorum Latinorum [CSEL] vol. III, pars 1 [Vienna: C. Geroldi, 1968]). Four volumes in Corpus Christianorum, series latina have appeared which include G. F. Diercks's critical edition of Cyprian's letters. See the excellent annotated four-volume translation of the letters by G. W. Clarke (who retains Hartel's numbering), The Letters of St. Cyprian of Carthage, Ancient Christian Writers Series, nos. 43, 44, 46, 47 (New York: Newman, 1984-86). A satisfactory English translation of the treatises has yet to be completed. Here I cite the translation edited by Roy J. Deferrari (New York: Fathers of the Church, 1958). Cyprian's deacon Pontius, who also accompanied him into exile at Curubis, has left a biography, Vita C. Cypriani (CSEL vol. 3, pars 3, xc-cx) and the Acta proconsularia (CSEL, vol. 3, pars. 3, cx-cxiv). Biographies and historical monographs concerning different aspects of Cyprian's life and thought will be referred to in the following notes; see especially A. d'Alès, La théologie de S. Cyprien (Paris: Beauchesne, 1922) and M. M. Sage, Cyprian (Cambridge, Mass.: Philadelphia Patristic Foundation, 1975).

${ }^{5}$ Clarke comments that Cyprian was perhaps chosen bishop by the plebs because of his eloquence, his social status, and his good name in the city (1.16). At about the same time in Pontic Comana, the laity were looking for a new bishop among the Christian members of the upper classes, someone "who appeared to be outstanding in eloquence, birth and other distinguishing qualities" (Vita S. Gregorii Thaumaturgi [MG $46.933 \mathrm{ff}$.] by Gregory of Nyssa). Cyprian uses the term laicus in Letters 52.12; 55.5; 55.11.3; 59.13.5; 65.3.3; 67.6.2; and 72.2.1. The term is not used in the treatises. Cyprian also
} 
into his systematic and pastoral theology of the Church. A rhetor by training ${ }^{6}$ and a copious epistolary writer by vocation, he both informed and reflected the thinking of many of his contemporary Christians. Because of the relative ease of communication among the local churches scattered about the Mediterranean, and because of Cyprian's habit of writing encyclical letters, having them copied, and making them generally public, both locally on a provincial level, and through other protometropolitan bishops in the Church universal, one can look to his letters as representative of important ideas in wide circulation within the pre-Constantinian Church. While he never wrote a formal treatise on ecclesiology, still a careful reading of his correspondence reveals a coherent theological justification for the inclusion of the laity in ecclesial discernment about three important areas of Church life: the election of bishops, the judging of penitents (i.e. readmission of lapsed Christians), and the assessment of clergy's orthodoxy and suitability to remain in office. In his practice of consultation and creating consensus, one finds a developed theology of the Church which I am convinced can be retrieved to undergird theologically the common ecclesial ground which many are seeking today.

As a hermeneutic for reading and interpretating these letters, I propose a presupposition of critical charity, suggested by Ignatius Loyola, similar to what Bernardin meant when he spoke of a hermeneutic of love and retrieval. ${ }^{7}$ By this I mean a commitment to refrain from systematically suspecting the honesty of those in positions of authority. Instead, I take Cyprian at face value when he writes about the laity's participation in church governance. I adopt this hermeneutic for three reasons. There is every evidence from his life that Cyprian was a person of integrity. ${ }^{8}$ Second, the theological support which he cites for his ecclesial practice is both consequent and convincing, coming as it does from plausibly orthodox beliefs about God, human history, and the nature of the Church. Finally, such a reading of the texts is useful,

calls the laity plebs (89 times) and populus. See Richard Seagraves, Pascentes cum Disciplina: A Lexical Study of the Clergy in the Cyprianic Correspondence (Fribourg, Switzerland: Editions Universitaires, 1993) 14-15.

${ }^{6}$ See the example of Cyprian's rhetorical training in Letter 52, a sustained invective against Novatus, Cyprian's arch-enemy. On Cyprian's use of polemic, see H. J. Vogt, Coetus Sanctorum (Bonn: P. Hanstein, 1968) $140 \mathrm{ff}$.

${ }^{7}$ Ignatius of Loyola suggests for the good of all parties that "every good Christian [be] more ready to put a good interpretation on another's statement than to condemn it as false" (Spiritual Exercises, trans. L. Puhl [Chicago: Loyola University, 1951] no. 22). See J. Bernardin, "Called to Be Catholic: Church in a Time of Peril," in Murnion, Catholic Common Ground Initiative 41.

${ }^{8}$ His conversion, ordination, and election all involved downward social mobility among his peers in Roman Imperial society. He was also willing and able to impoverish himself financially, distributing his considerable wealth among the Christian poor, to go into exile for an extended period of time, and finally to suffer martyrdom by beheading as a consequence of his faith and actions. 
for it makes possible a constructive retrieval of underlying theological attitudes and orientations applicable to present ecclesial reality.

During Cyprian's term in office, the Carthaginian Church was experiencing twofold pressure. The Decian persecution, though capricious and uneven, was felt in Carthage. Cyprian's community was also riven internally by theological disagreements, captious personalities, and outright treachery. Cyprian theorized and executed a number of pastoral responses to these challenges in order to defend and promote orthodoxy and communion, which in his eyes were expressions of the single, deeper ecclesial ideal of peace in Christ. The Church would live in peace, if and to the extent that all its members lived in attentive and discerning obedience to God's providential care, as expressed through the gospel message and lived out in dynamic interaction within the Christian community. In order to discern God's will for the Church, Cyprian stated that from the beginning of his episcopate, when he felt obliged to accept the office at the insistence of the people, he established that as bishop he would do nothing without the consent of the people. ${ }^{9}$ In the process of reaching important decisions that touched on both orthodoxy and communion, Cyprian saw in the consultation and the consensus of the people an essential indication and confirmation of the will of God. The peace of the Church was at once the condition and the consequence of such consultation and consensus. This practice arose from the pastoral exigencies of the situation, from the available structures of organization and governance in the surrounding cultural milieu, and from Cyprian's deeply held theological convictions.

In Cyprian's basic faith-vision, God is intimately involved in the life of the world and of the Church. ${ }^{10}$ God acts decisively in history, and human beings, graced with divine help, are able to discern God's will in specific circumstances. Divine providence is primarily revealed in Scripture and in the tradition of the Church, and secondarily through revelatory dreams (visiones), especially, though not exclusively, those of bishops. The communal interpretation of these revelations allows the faithful knowingly and prayerfully to submit in obedience to the Spirit. ${ }^{11}$ For the good of the Church, the divine will can manifest itself phenomenologically through the mediation of ecclesial persons and

\footnotetext{
${ }^{9}$ Letter 14.4.

10 "So, then, Cornelius took on his office of bishop, obtained neither through any corruption nor any extortion but through the will of God, who is the one who makes bishops" (Letter 55.9.1). A person who uses such sinful artifices to gain ecclesial office is clearly not a bishop. Here one sees that Cyprian's general worldview was rather rigidly dichotomous: either one obeys God in all things and thereby does good, or one succumbs to the devil, disobeys, and acts out of disbelief. Perfidy is the opposite of faith; false religion is the only alternative to the one true religion (De Dominica oratione 14).

${ }^{11}$ Cyprian would often claim that God had revealed to him in a dream the course of action he was to take, though these decisions were also always backed up by reasonable arguments and by appeals to Scripture or tradition. Private revelations alone, even those accorded by God to a bishop, are insufficient justification for an exercise of episcopal authority. In Letter 11, e.g., the exhortation to constant prayer is based upon both
} 
practices. God's will directs historical events as well, such as the persecutions, though here God's ways are veiled, at times due to naturally limited human knowledge, at times due to sinful blindness. ${ }^{12}$ In all these cases, the idea of mediation plays a key role for Cyprian. This conviction undergirds his reliance upon the faithful for help in discerning God's providential will for the Church. Cyprian paid special heed to the propriety of procedural form in ecclesial matters as a guarantee that the Church was correctly discerning the divine mind and will. The careful following of established customs was as important as a prayerful appeal for divine help in such instances. Within these customs, the active participation of the laity in ecclesial discernment was essential in a number of cases. To see this, I explore the case of episcopal elections, then look briefly at similar applications of his fundamental insight to the readmission of the lapsed and to the deposition of unworthy bishops.

\section{THE CHURCH RECEIVES FROM GOD A BISHOP}

Few events in the life of a local church at that time were more crucial to the promotion of orthodoxy and communion than the election of a new bishop. When the procedure was properly conducted from start to finish, Cyprian could confidently claim that the entire event was the will of God. ${ }^{13}$ The faithful unite in truth around the new bishop, chosen by God and by them, who speaks and acts for God and for them in the Church. ${ }^{14}$ In a process at once institutional and charismatic (both human and divine), the customs of the Church, in this case the rules for the election and ordination of a new bishop, were the outward, formal manifestation of the invisible, providential reign of God in the Church. In this case, the form included the considered and prayerful assent of the entire church membership, both the local community and the Church universal represented by neighboring bishops.

Cyprian described this complex process by the use of four technical terms, each entailing an essential and necessary step in a single, in-

the explanation of the symbolism of a dream (Cyprian's?) and appeals to Paul's Letter to the Colossians and to Luke's Gospel.

${ }^{12}$ Cyprian's first impulse was to explain away the suffering of the Church, seeing behind each new wave of civil harassment either divine punishment or testing.

${ }_{13}$ "So, since He declares that not even events of the least account take place without the will of God, would anyone suppose that events of the highest and greatest importance can take place in the Church of God without God's knowledge or permission?" (Letter 59.5.2).

14 Cyprian defines the local church as having been "established upon the bishop, the clergy and all those who remain faithful" (Letter 33.1.2), by which he means to indicate the essential aspect of communion as a mark of the true Church, as opposed to the vague notion of the schismatic group who wrote to him "in the name of the Church" (Letter 35). As a rejoinder to this faction which aims to promote its own bishops, Cyprian asserts that Christ alone appoints and protects his bishops (Letter 59.6.2). 
tegrated operation: $\imath u d \imath c \imath u m$, testımonıum, suffragıum, and consensus, terms that we may tentatively define as "choice," "testimony," "election," and "acceptance." Through a philological analysis of these four key words in context, Osawa has sketched out a solid "field of meaning" for these terms by bracketing exceptional, marginal, and questionable occurrences. ${ }^{15}$ This is helpful, since Cyprian sometimes responded with passionate and imprecise rhetoric to specific challenges to himself or the community.

Iudictum is the action of the divine intellect and will, the process by which God chooses and installs the new bishop. Cyprian assigned a surprising variety of subjects to this all important action: God, Christ, the divinity, the bishops, and all the faithful. This richness begs the question "Who is judging here?" The central idea for Cyprian is $\imath u$ dicıum Del, for God "chooses" the bishop. ${ }^{16}$ God is the initiator and the guide of ecclesial action, a process which includes rather than denies the participation of free and faithful human agents. And while Cyprian places the $\imath u d \imath c \imath u m$ Del prior to all other aspects of the process, both chronologically and formally, the manifestation of God's choice becomes clear to human participants only through the successful conclusion of the entire process. When he was forced to judge the validity of the election of other bishops, Cyprian employed a hermeneutic of propriety, parsing the process of particular elections to see whether all the essential elements were clearly in place and without defect. Human beings "judge" in this technical sense only insofar as they are people of faith, for this judging of formal elements is really an act of religious discernment. So convinced is Cyprian about the divine authorship of just ecclesial action that the terms iudicıum epıscopı and $\imath u d \imath c \imath u m$ omnıum are practically interchangeable with $\imath u d \imath c \imath u m ~ D e v$. To judge correctly is to discern God's intellect and will. In this, the collegial judgment of the bishops, their knowing and choosing, is essential. They need not be especially numerous, but they must be of one mind, for the unanimous decision of a gathering of bishops in good standing (in accord with Scripture and tradition and united with the laity of their local churches) is a visible sign to all the faithful of the very choice of God. ${ }^{17}$ Cyprian also assigns this role of discerning judg-

\footnotetext{
${ }^{15}$ Takeo Osawa's doctoral dissertation at the University of Wurzburg studied the process of episcopal elections according to Cyprian (Das Bischofseinsetzungsverfahren bet Cyprian Historische Untersuchungen zu den Begriffen iudicıum, suffragıum, testlmonıum, consensus (Frankfurt Lang, 1983) Osawa contextualızed Cypran's letters in the events of his life and times, both ecclesial and secular, and then profiled Cyprian's thought patterns and presuppositions in an effort to elıminate doubtful or imprecise cases Yet in these "marginal cases," some of Osawa's own unexamined prejudices become clear

16 "Are we really in a position to rebel in any way against God who makes us bishops?" (Letter 331 to Rogatianus, bishop)

17 The iudicium omnium is an extension of this same principle of unanimity as a sign and a manifestation of the efficacious will of God to the entire assembly of the farthful So ıudicium is used by Cyprian to designate the decision of God who initiates and guides
} 
ment to the entire community, iudicium omnium, including thereby the laity.

Another essential part of the larger process is that of the testimonium. The agents of this action are God, the bishops, the clergy and, again, the entire local community. Testimony in the form of a character witness or an argued support could either be oral or in writing if, for example, the bishop of a neighboring city were unable to attend yet wished to participate. These testimonies were descriptions of the qualities and the qualifications of those men deemed suitable, normally but not exclusively drawn from the ranks of the local clergy. Exceptions to this last custom are notable, since they include Ambrose, Basil, Augustine, and in a way Cyprian himself, who had only just been ordained a priest when he was chosen by the people for the episcopate. The praise and the reservations expressed by members of the local church informed the bishops from the neighboring towns and cities. ${ }^{18}$ Where there was unanimity of opinion, Cyprian spoke of the testimonium omnium as signifying the testimonium Dei, for, again, univocity was for Cyprian an indication of the will of God. ${ }^{19}$ Testimony was at once an ecclesial judgment and a divine approbation, for it affirmed and attested to the worthiness and the aptness of the person to be ordained in the eyes of God and the Church.

Did the laity testify? The most obvious evidence one has lies in cases of election by popular acclamation. Cries of "Ambrose, bishop!" were testimony to the public perception of the character and worthiness of the man. ${ }^{20}$ Cyprian too was ordained in accord with such popular acclamation, and against the better judgment of at least some of the local presbyters. As bishop, Cyprian continued to listen to the people, saddened occasionally not by their outspokenness but only by their

the entire process of the choice and the installation of the new bishop. In this and in other cases, Cyprian understands unanimity as a mark of the true Church. Truth and the Holy Spirit are with those who are in universal communion, a condition not of numerical but of theological importance (see Cyprian's treatise De unitate ecclesiae 12).

${ }^{18}$ Did the laity give oral or written testimony? Agreeing with E. W. Benson (Cyprian, His Life, His Times, His Work [London: Macmillan, 1897] 28), X. S. Thani Nayagam posits that the laity expressed their approbation "by their silence" (The Carthaginian Clergy during the Episcopate of Saint Cyprian [Tuticorin: Tamil Literature Society, 1950] 59). He offers no evidence in support, though the image of an entirely passive laity complements his hagiographic portrayal of Cyprian as the serene ecclesial authority figure.

19 Osawa 90.

${ }^{20}$ Ambrose's later practice as metropolitan was expressed in his letter to the Church at Vercelli (Letter 63.2; CSEL, vol. 82, pars 10, tome 3, p. 236 [Vienna: Holder, 1982]). Chiding the people for the many dissensions in the community which had blocked the formation of a consensus and a choice of a new bishop, Ambrose reminded them of their past experience, when they had chosen Eusebius: "Justly was it believed that he whom all had demanded was elected by the judgment of God." He urges them to self-restraint, faithful prayer, justice and peace as ways of uniting themselves with Christ and thereby making a sound judgment. 
discord and rancor. ${ }^{21}$ It is unclear whether the first dream mentioned in Letter 11 was intended to describe an episcopal election, but if it does, then it is consistent with Cyprian's general theology of the laity: they need to be actively in accord with the clergy so that the whole Church can be "united together in making our prayer" in order not to vex God who offers to give that for which (or "him for whom") the faithful petition. As will be clear in the cases of readmissions and rejections, Cyprian is constant in his attention to the voice of the plebs. It was by their divinely inspired voice that he took office, and it would be by their divinely sustained faithfulness to the truth that he would exercise that office. ${ }^{22}$ So one can conclude that at least some cases of active lay testimony were known and condoned by Cyprian as both theologically correct and ecclesially proper.

The testımonıum was essential to the electoral process, for the assembled bishops would generally have only secondhand knowledge of the possibiles. That unworthy persons attempted by various means to secure episcopal office is well recorded in the conflict between Cornelius and Novatian in Rome. Cyprian took very seriously the conflicting testimonies coming out of the capital at the time of Cornelius's election, leading him to defer recognition of the new bishop until he could secure firm evidence of his proper election, ${ }^{23}$ i.e., of the unanimous support of the local church, and so of God's manifest will.

Episcopal election did involve some type of actual voting, yet suffraglum is a term whose meaning for Cyprian is hard to pin down. With only the local community as its subject, it seems to function as a sort of synonym for testımonium. Cyprian's consistent use of the term suffragıum leads one to observe the following: it always has a positive sense, indicating a general support for the whole of the process, and it is realized by and within the local ecclesial community. If one looks at Cyprian's cultural and ecclesial milieu, one finds interesting layers of meaning for this technical term. In the Roman Republic, the suffragium was literally a wooden voting tablet. Figuratively, the term denoted suffrage as a right and a practice. Voting was, of course, a fairly widespread custom in the ancient world, even beyond Roman imperial

21 "And then the congregation standing by was enjoined to ask [God] on behalf of certain people pointed out to them, but in putting their request their voices were discordant, their wills conflictıng, and He who had said 'ask and you shall have' was exceedingly displeased at the fact that the people were divided and at variance (Letter 1131 )

${ }^{22}$ Letter 43 was written directly to the laity of the Church in Carthage to affirm them in their faith and to warn them against the plots of troublesome presbyters Cyprian reminds the people that they had appointed him in accord with the will of God They should now stand fast in faith

${ }^{23}$ When the propriety of Cornelius's election became clear to Cyprian, he would defend the entire process as irreversible "once a bishop has been made and approved by the testimony and judgment of his colleagues and people, it is just not possible for another to be appointed "It is clear that Cyprian affords here the twin capacities of testimonium and $\imath$ idıcium to both the assembled bishops and to all the farthful people 
bureaucratic culture. ${ }^{24}$ Regarding the early Church, there is no little debate among scholars as to whether (and how) the laity voted in episcopal elections. ${ }^{25}$ Here one notes that, for Cyprian, the suffragium was an essential step in the whole process; it guaranteed the presence of all the members of the local church in general assembly as a requirement for the designation and installation of the new bishop. For example, Letter 67.4.1 states that "bishops are chosen in the presence of the laity and before the eyes of all (sacerdos plebe praesente sub omnium oculis deligatur)." The new bishop was chosen in a solemn ceremony that included public testimony and scrutiny. ${ }^{26}$ It seems most

\footnotetext{
${ }^{24}$ Osawa reports that into the third century, the appointment of imperial officials had retained a public formalism which included the four elements mentioned in this study. The iudicium was finally in the name of Caesar and was performed by him or by a suitable delegate. The judge received the names of the candidates presenting themselves or by a patron and selected one for each office. Testimonium was then held before the Senate in the case of the candidati Caesaris (the testimony could have been made by the Emperor himself or by his delegate). The Senate accepted Caesar's proposals and designated them to be official candidates for office. These were then presented to the plebs who confirmed the candidates by acclamation (so the vote was a simple "yes" or "no" rather than a choice between different candidates), thus giving their suffragium. In the days of the Republic, this "vote" had involved an actual ballot, perhaps in the form of a wooden token, the original meaning of the suffragium. The consensus omnium was the more general accord, among the populace and the gods, giving the state both a political and a theological justification of the legitimacy of its bureaucrats. After the battle of Actium, this process became a mere public formality in the political sense, yet as a public religious rite it was meant to carry great symbolic weight (see Osawa 146). For Greek and Jewish sources of popular electoral processes in religious and philosophical associations in the Eastern Mediterranean, see G. Busolt, "Griechische Staatskunde," in Handbuch der klassischen Altertumswissenschaft (Munich, 1920) 1000-71; F. Poland, "Geschichte des griechischen Vereinswesens," in Preisschriften von der Fürstlich Jablonowskischen Gesellschaft zu Leipzig (Leipzig, 1909) 38.417; and S. Krauss, Synagogale Altertümer (Berlin, 1922) 152-54. On the election of the Archons by Jewish communities in the Diaspora and at Qumran, see E. Ferguson, "Qumran and Codex D," Revue de Qumran 8 (1972) 77.

${ }_{25}$ Osawa is certain that they did not vote in any formal way (79). Thani Nayagam expresses a similar opinion (59). Yet in Letter 38 Cyprian dutifully records the established custom of his Church, namely that before clerical appointments were made, he would normally consult with the presbyters, deacons and all the laity, and in counsel together they would weigh the characters and qualities of each candidate. In Letter 67 Cyprian reminds the laity explicitly that they "have in [their] hands the power to select bishops who are worthy." Gregory of Nyssa, in his life of St. Gregory Thaumaturgus, reports that the laity of Comana had proposed several candidates and had invited Gregory to come for the ordination, but they were unable to come to a consensus until Gregory proposed a certain Alexander. After reviewing the literature, E. Ferguson concludes that voting was widespread in the churches of the East, though quite varied in form from city to city ("Origen and the Election of Bishops," Church History 43 [1974] $26 \mathrm{ff}$.).

${ }^{26}$ Were the local laity able to suggest names? Were the laity asked their reasons for such suggestions? Did they give testimony directly to the assembled bishops, or were their views filtered through the local clergy? See the following details: "... when an episcopal ordination is to be duly celebrated, all the neighboring bishops in the same province convene for the purpose along with the people for whom the leader is to be chosen, ... and we note that this procedure was indeed observed in your own case when our colleagues Sabinus was being ordained ... by the choice of the whole congregation
} 
likely that the people served as a sort of tribunal, for they would have known the conduct of the one who was presented.

Did the people have an active voice? Did they have veto power? One can make the plausible conjecture here concerning two types of suffragium omnium. During a period of prayerful exchange and discussion (murmuratio), the members of the local church would answer the inquiries of neighboring bishops about the life, character, and religious practice of various persons under consideration. During the liturgical assembly, where the ordination took place, the people would voice approval (or disapproval ${ }^{27}$ ) of the person presented by the bishops. The distinction between these two modes would be chronological as well as formal, for the entire process could have taken several days, during which time the community prayed to God for guidance.

The process culminated in a liturgical assembly at which the ecclesial discernment was brought to a conclusion. Certain earlier phases were recapitulated and represented, the new bishop was formally presented, and the choice was effected. The suffragium omnium was signaled by popular acclamation and was then followed by the imposition of hands by the bishops, both of these being visible signs of the consensus of the Church. The impositio signified and realized the belief on the part of all present that the process was complete, the will of God had been made manifest, and the Church had been given a bishop by God. In order to seal the entire process, the new bishop would then complete the liturgical assembly by presiding at the Eucharist, by which the whole community, in union with other local churches, would realize their orthodoxy and their communion in the peace of Christ.

Linked intimately with the notion of reception, and presented as an essential element in the ecclesial discernment of the divine will, consensus had for Cyprian two levels of meaning. First, it was the universial accord among a group of bishops (either present or by proxy, either

and by the will of the bishops ... the office of bishop was conferred on him and hands were laid on him" (Letter 67.5). Osawa and Thani Nayagam both assign to the laity a silent role of reception and passive role of acceptance, though they both make such a judgment based upon their interpretation of the silence of Cyprian on this subject. Osawa allows only that the laity may have discreetly transmitted their opinions to the local clergy (108-9). Here one can raise the question of the interpretation of this silence through the cultural lens of the cultural backgrounds of these two authors. Osawa has adopted a position on the activity of the laity which is finally quite difficult to defend. Eager to discount any traces of a protodemocracy among the early Christian laity, he contrasts their docility, piety, and obedience with the obstreperous Roman rabble. Osawa claims that unanimity was habitual, ignoring the rancor concerning both Cyprian's and Cornelius's elections. He states as a general principle that "overall no significant differences of opinion between the bishops and the local community could have appeared." Such a placid assessment of the third century is hard to support by the data. For this same attitude in Thani Nayagam, see n. 18.

${ }^{27}$ In the case of the election of Cornelius in Rome, the lack of univocity was a major problem for Cyprian; he did not recognize the election until a clear consensus was manifest, perhaps several months after the initial ordination to the episcopate. 
during or after an election ${ }^{28}$ ); second, it was an unanimous accord of the entire Church. While only the former enters into his discussion of the election of a bishop, both meanings apparently indicated to him the iudicium Dei. The unity of the Catholic Church, manifest in the consensus of the gathered bishops, was a convincing sign of God's judgment. At the same time, God's will thus manifest was the guarantee of the authority and the legitimacy of the new bishop, as it was of the entire process. This argument may be formally circular, but is so because it reflects a hermeneutical circle of mutual approbation, a unity, composed of multiple parts which were mutually confirming and justifying. So one sees that iudicium, testimonium, suffragium and consensus were all necessary in Cyprian's thinking as integral and essential parts of a whole process of election and installation of a bishop. Indeed, any bishop who has gained his place against the law of ordination and without having received this office from the Church is clearly not a bishop by divine appointment. ${ }^{29}$ In this process, the laity played an active and an essential role in the discernment and the accomplishment of God's providential care for the Church.

\section{CHURCH RECEPTION OF THE LAPSED}

A second instance where Cyprian sought the common accord of the faithful was in the readmission of Christians who had apostatized during persecution. In this question, Cyprian was again dealing with the two principal challenges of his episcopate: the defense of doctrine and the promotion of the unity of the Church. His theology of reconciliation involved the active participation of the faithful laity, a manner of proceeding which was both politically astute and pastorally useful, though here again it seems that Cyprian's ultimate reason for this consultation was theological. Cyprian believed that the persecution of the Church was God's will, an intended chastisement of the community of the beloved in order to steel the faith of the strong, to expose the sinfulness of the weak, and to forge ever stronger bonds of mutual love among all the members of the Church in the collective experience of suffering and reconciliation. With the cessation of persecution and the return to peace, Cyprian expected that the Church would be an even stronger communion, thanks to the example of courage on the part of the confessors and martyrs, and to the exposure of the secret sins of the

\footnotetext{
${ }^{28}$ Conprobatio was subsumed under the consensus episcopi. It was accorded through the letters of support which were sent by sitting bishops who were absent at the election but who, after the fact, sent letters of recognition, support, and blessings to the new ordinary. Since one of the functions of a bishop was to serve as a means of communication and communion with other local churches through his membership in the episcopal college, these letters of conprobatio were an important instance of the episcopal ministry.

29 ". . . those who establishes themselves as leaders without any law of ordination, who assume the name of bishop for themselves although no one gives them the episcopacy ..." (De unitate ecclesiae 10).
} 
apostates, ${ }^{30}$ who would first confess their sins and be judged by the assembly before regaining their places among the faithful. In Cyprian's view, the careful readmission of the lapsed would give the Church an opportunity not simply to heal the wounds caused by the persecution but to cull the fruits of a divine lesson. For this to happen, Cyprian demanded a strict respect for the formal process: the bishop, with the clergy and the faithful, were to judge each case on its merits. If some confessors chose to act unilaterally, admitting the lapsed to full communion by a personal and private judgment, they were robbing the Church of an opportunity to discern in common. To channel the activities of the strong in accordance with his theology of the Church, Cyprian again advocated the consultation of the laity, courting the active participation of all (including, therefore, the confessors) in a communal discernment for the sake of the integrity of the Church.

From exile, Cyprian strongly encouraged the confessors to wait patiently until such time as circumstances would permit a general synod of all the faithful, at which these important decisions could be reached together. In a letter addressed to his "brothers among the laity," Cyprian writes that, "after the Lord has first restored peace to us all, and as soon as we have returned to the Church, these requests [for readmission] will be examined individually, in your presence and with the help of your judgment." ${ }^{31}$ The insistence on patient waiting until peace be restored is a recurrent theme in Cyprian's thinking. Since proper procedure was necessary in order that the will of God be heard and understood, peace was that necessary condition for the possibility of procedural propriety. Individuals were not to act on their own, for despite ecclesial office or integrity of personal faith, individuals could err in discerning God's will in a specific situation. Not even the bishop was able, as an individual, to judge such a matter or make a decision when the matter by its very nature required "the counsel and opinion of us all." ${ }^{2}$ Unilateral action on the part of any individual threatened the unity of the Church, which was to be maintained through humble listening, in charity, to all. To fail to respect the communal character of ecclesial discernment would demonstrate an overreaching haughtiness and dangerous ignorance of the Church's nature. On the contrary, honesty in speech and in listening, acquired through humility and self-discipline, was necessary for true communion and were signs that

\footnotetext{
${ }^{30}$ Cyprian understood the episode not as a political persecution but as a divine test: "... although we deserve more on account of our sins, the most merciful Lord has so moderated all things that all that has happened seems a testing rather than a persecution" (De lapsis 5).

${ }^{31}$ Letter 17.1.2. In Letter 17.3.2 he reiterates his determination to adjudicate matters "in accordance also with your judgment."

${ }^{32}$ In a letter to his presbyters and deacons, Cyprian seems quite clearly to enunciate as a general principle that ecclesial decisions which are of everyone's concern must be reached with the active participation of all (Letter 26.1.2).
} 
the members of the Church were living quietly and peaceably in accordance with the discipline of the Lord. ${ }^{33}$

THE CHURCH CASTS OUT THOSE IN ERROR

In Cyprian's day, as in ours, local churches had to deal on occasion with the problem of deacons, presbyters, and bishops who for various reasons proved themselves unworthy of the office that they had occupied for a time. Even if their appointment or election had been proper and true, it happened that individuals fell from grace, were seduced by unorthodox ideas, or were corrupted by a love of money or power. In these cases, Cyprian was convinced that just as God had first called these men to service in the Church, so too would God remove the offending persons from office. And just as the faithful laity had had a part in their election, so too would the laity have an active part and an essential role in the judgment and removal of unworthy clergy from office.

In the case of his own local community, Cyprian noted in a letter to his presbyters that those "rash, impetuous, and arrogant" clerics who act without the authority and permission of the bishop will be tried before him, the confessors, and "all the people."34 Cyprian here mentions three subjects as involved in the act of ecclesial judgment. We can understand each of them as participating in that unified action in a specific way. The local bishop, the heroic believers, and the entire body of the faithful are three elements within the local church. The confessors are praised for the strength of their faith, a strength which, under the name of humility, gives rise to a keen ability to perceive the sins of others. But lest this gift be exercised outside the bonds of unity and thus become a threat to that unity, Cyprian places it in conjunction with the faith of all the laity who are at peace. The laity too possess an ability to judge rightly, for their status of peaceful communion is both a sign of, and a condition for, the active presence of the Holy Spirit, a presence that protects and promotes ecclesial peace. Finally, the bishop has that graced institutional authority to animate the entire process within the bounds of orthodoxy and in the bonds of universal communion, and so to lead the entire process to a peaceful conclusion. $^{35}$

On those occasions where the bishop himself was suspect, Cyprian assigned to the laity not just the right but the duty to judge and, if need be, to reject and replace an unworthy ordinary. For "the faithful are not to beguile themselves with the notion that, while they are in communion with a bishop who is a sinner and acquiesce in their church leader's wrongful and unlawful exercise of episcopal powers, they can re-

\footnotetext{
${ }^{33}$ When he says that a Christian is to stand under the "discipline of the Lord," Cyprian seems to mean both an obedience to Scripture and tradition as well as a charitable treatment of all (Letter 33.2.2).

${ }^{34}$ Letter 16.4.2.

${ }^{35}$ Letter 43.4.1.
} 
main themselves untouched by the infection of his offense." ${ }^{36}$ In one case, an appeal was made to Rome by two Spanish bishops who had been exposed as heretics and deposed by their congregations. It appeared that Pope Stephen may have been inclined to support them in their efforts to regain their places. In the meantime, the newly elected replacement bishops made an appeal to the synod of African bishops in a quest for support against the old claimants. Cyprian suggests a more basic solution to the problem. "The power both to select bishops who are worthy and to reject those who are unworthy" lies in the hands of all the faithful members of these two local churches. One can see here a clear application of Cyprian's theology of the Church: God chooses as an essential instrument of church life the active participation of the laity in those important decisions which affect the faith of all. Appeals over the heads of the faithful laity to geographically distant sources of authority ignore and deny the most immediate and obvious instrument of God's will.

\section{THE CONDITIONS FOR ECCLESIAL DISCERNMENT}

Cyprian's inclusion of the laity may have been inspired by a number of factors. Outside the Church, the consultation of the plebs had become widespread in the Roman Empire in both familial and public life ${ }^{37}$ It is reasonable to assume that Christians had come to expect it in their ecclesial life as well. Cyprian's option for the active participation of the laity in important instances of church life may be another example of borrowing a custom from the Roman world and imbuing it with Christian theological meaning. It may have represented a tactical choice on the part of a weakened bishop in order to govern a divided church. Cyprian was unable or unwilling to rely solely on his official authority as bishop. But it also exemplifies the logical consequence of his theology of consensus. In this process of discerning questions which affected the entire community, the bishop stood in a reciprocal relationship to the other members of the local church.

Certainly, Cyprian understood the bishop to be the primary teacher of sound doctrine. But a good teacher remains always a good learner. ${ }^{38}$

\footnotetext{
${ }^{36}$ Letter 67.3.1. This remarkable letter, signed by 37 African bishops, was sent in support of the theological propriety of the decision of the Christian communities in two Spanish towns which had excluded their fallen bishops and had replaced them with worthy men. Cyprian's hand is clear in the writing, which rehearses his theology of divine activity in the election and removal of bishops by the local church based upon sound evidence and proper procedure. Since failure to act decisively would corrupt all the members of the Christian community, it behooved them to assume their responsibility for the maintenance of sound doctrine and the peace of the community.

${ }^{37}$ Clarke notes that many such councils had, by the third century, acquired quasilegal status and great de facto power (Letter 1, n. 3, 1.151).

${ }^{38}$ A good bishop is both doctus and docibilis, "a teacher and teachable" (Letter 74.10.1). In the context of this letter to bishop Pompeius, Cyprian identifies Scripture and the tradition of the Church as the two chief sources of divinely revealed truth for a
} 
It is only by listening to the Spirit that the bishop can obey God and preserve both unity and orthodoxy. At various times and in various ways, the Spirit speaks through different members of the community, to whom the bishop must therefore pay heed in order to hear God's voice and obey God's will for the Church. Through an open-ended learning process which involved the entire Christian community, the bishop could hear, understand, and pronounce the decision of God in and for the Church. The requirements for the laity are of a similar nature. For them to discern the will of God for their community, they must be people of faith and discipline, open to the promptings of the Spirit within the assembly. For the laity no less than for the clerics, orthodoxy and communion, in peace, are conditions for the possibility of religious discernment. To act in such a way as to break communion and to ignore tradition would be to engage not in ecclesial discernment but rather in partisan politics. St. Paul had already identified this attitude as "factions or party spirits," and he listed it among other sins in Galatians 5:20 as a work, not of the Spirit, but of the flesh.

While the general movement of the century was toward a more passive role for the laity in synods and councils, Cyprian continuously accorded to the faithful laity an essential place in the Church and a variety of active responsibilities for the integrity and the unity of the Church. This corresponds to his image of the Church, founded by Christ on Peter, "established upon the bishops, the clergy and those who remain faithful." ${ }^{39}$ The active participation of the faithful, respectful of one another and of the procedural forms of the tradition, was for Cyprian both the condition and the outcome of peace, that natural state of the Church.

\section{THE PRESENT VALUE OF AN ANCIENT PRACTICE}

The Catholic Church in the U.S. at the close of the second millennium is faced with challenges different from those of the Carthaginian Church of the third century, yet the present does share with the past an urgent need for common ground within the faith of the Church in order to discern as a community God's gracious offers of help. Cyprian's theological reasoning locates that common ground in the practice of communal discernment culminating in peaceful consensus of all the members of the local church. This ecclesial practice rested upon and furthered the orthodoxy and orthopraxis of the community, its belief in and communal action in accord with the truth of the gospel. Since God was the principal actor in the life of the Church, Cyprian

\footnotetext{
bishop. In other places, Cyprian included the considered judgment of the laity among the principle sources of divine inspiration for effective and faithful ecclesial leadership.

${ }^{39}$ Writing in response to an anonymous letter of complaint and rebellion, Cyprian describes true ecclesial communion as built upon honesty, humility, and charity, virtues which manifest themselves in submission to the discipline of the Lord, obedience to the bishop, and peace with all the faithful (Letter 33.1.2).
} 
could place "the will of God" and "the agreement of all" in apposition, giving them equal weight, in order to signify that God both sustained and acted through proper ecclesial processes. It is exactly this type of structured inclusivity, in charity and in faith, that can help to rebuild and strengthen communion in orthodoxy and peace in the Church today.

If one compares Cyprian's pastoral solutions to current ecclesial realities, one can begin by noting that Cyprian's juridical and technical language appears to have survived in vestigial form in the ritual today ${ }^{40}$ According to the rubrics currently in force, a spokesperson for the local church community, being present at the ordination of the new bishop, asks the invited bishops-at least three in number-to ordain a specific candidate for service as bishop. ${ }^{41}$ The presentation of the bishop-elect is followed by a testimonium (in the form of a mandate from the Holy See), after which the formal consent of the people is solicited. ${ }^{42} \mathrm{~A}$ further examination is made as a public reenactment before all the people of the previous deliberations. The laying on of hands follows, then the new bishop enters into his function as servant of the people in the eucharistic liturgy, presiding over the concelebration if the ordination has taken place in his own church. ${ }^{43}$ Many elements of the external form of the process described by Cyprian have perdured, yet one may rightly wonder whether either the theological content or the deeper ecclesial praxis have survived. While laity may be present at an episcopal ordination, their active participation is not essential; indeed, for those men ordained to be "nonresidential" bishops, i.e. pastors without flocks, the point is moot. In the other two cases which were examined, readmission of notorious sinners to full communion or condemnation of errant clergy, members of the laity may serve on ecclesial tribunals, but their presence is not deemed mandatory. The active participation of the laity is not essential in any of these cases, while it clearly was for Cyprian.

At the outset of my study, I asked two principal questions: whether and how the laity ought to participate in ecclesial discernment of matters of weight and moment in the life of the Church. Cardinal Bernardin's Common Ground Initiative has sought to make a modest contribution in a large and complex situation, sketching out the conditions of faithful Catholic dialogue. Cyprian's procedures lend support to the late cardinal, offering theological justification for the inclusion of all in discernment, and instructing any who would participate regarding the terms and conditions for such participation. Ecclesial discernment is a communal task of the Church, but it makes high demands on all participants. They must work hard at being open to God who speaks through Scripture, through the tradition of the Church, and through

${ }^{40}$ Rite of Ordination of Deacons, Priests and Bishops (Rome, 1969) chap. 5.

41 Ibid. nos. 1, 2, 16.

43 Ibid. no. 5.

42 Ibid. no. 17. 
the community as a whole. Participants must also work within the structured procedures of the community, respecting the different but mutually dependent roles of various persons within the community, including that of bishop as animator of the local community and essential link with the universal community of churches. And they must enter into the process with a predisposition of charity toward all other participants in the discernment. If these conditions are respected, then one can justly propose Cyprian's pastoral praxis of ecclesial discernment as a theological model for the Common Ground Initiative. It is both possible and desireable to imagine an active lay participation in determining the future course of the Church in the U.S. To steer this discussion in the direction of communal religious discernment, the animators of the discussion must work against the secularization of this dialogue, i.e., the resort to partisan political methods of debating and deciding, whether they be democratic or autocratic. Instead, in accord with the renewed theological importance of the laity as full members of the Church since Vatican II, Cyprian's vision of true ecclesial discernment suggests a hopeful alternative, one that in its methods supports and affirms its intended outcome, the orthodox communion of the Church in the peace of Christ.

Cyprian's vision of a participative laity for the building up of the faith of the Church was based upon the belief that God was providentially active in the life of the Church. His theology is certainly respectful of the authority of the bishop, but not to the exclusion of a communal responsibility to discern the will of God. Much of Cyprian's vision of Church is perennial: the strong bonds of charity which ought to unite the Church are themselves gifts from God, received in faith by all members of the Church who ask in turn for divine help in the living out of the ramifications of these gifts. Such persons would display and enact their holiness "who are mindful of the discipline of God ... who observe justice scrupulously, who are steadfast in faith, humble in fear, brave in enduring all suffering, mild in sustaining injuries, ready to show mercy, of one mind and heart in fraternal peace." tians would find common ground for lives of holiness, for that ground would itself be holy.

${ }^{44}$ De habitu virginum 23, in Saint Cyprian: Treatises, trans. A. E. Keenan (New York: Fathers of the Church, 1958) 25-52. 